\title{
The Diversity Explanation of the Eleventh Amendment: A Reply to Critics
}

\author{
William A. Fletcher $\dagger$
}

During the past dozen years the original meaning of the Eleventh Amendment has become a matter of active controversy, both among legal scholars and among the justices of the Supreme Court. ${ }^{1}$ Modern Eleventh Amendment doctrine remains governed by the traditional view, which in gross outline holds that the amendment is a jurisdictional bar prohibiting the federal courts from hearing unconsented suits brought against states by out-ofstate citizens or by foreign citizens or subjects. ${ }^{2}$ The principle from which the amendment derives, though not the text of the amendment, similarly bars unconsented suits brought by in-state citizens. $^{3}$ The amendment's bar may be avoided or overcome in a number of ways, the most significant of which are suits against individual state officers for prospective relief, ${ }^{4}$ Congressional abrogation of the amendment by explicit statutory language, ${ }^{5}$ and volun-

$\dagger$ Professor of Law, University of California, Berkeley, School of Law (Boalt Hall). B.A. Harvard, 1968; B.A. Oxford, 1970; J.D. Yale, 1975. I wish to thank my friends Akhil Amar, Vicki Jackson, Lawrence Marshall, William Marshall, and Calvin Massey for their valuable criticisms and comments on this article. I hardly need add the customary disclaimer that the conclusions I reach are not shared by all of those to whom I owe thanks.

1 Justice Brennan, along with Justices Marshall, Blackmun, and Stevens, has argued for a change in Eleventh Amendment doctrine based on the new historical understanding of the amendment. See Atascadero State Hospital v Scanlon, 473 US 234, 247 (1985) (Brennan dissenting); Welch $v$ Texas Department of Highways and Public Transportation, 483 US 468, 478-95 (1987) (Brennan dissenting). The other five justices have declined to acknowledge the validity of this historical understanding, or to incorporate it into modern law. Welch, 483 US at 468 (Rehnquist, White, and O'Connor); Pennsylvania v Union Gas Co., 109 S Ct 2273, 2296 (1989) (Scalia and Kennedy).

2 Edelman v Jordan, 415 US 651, 662-63, 677-78 (1974).

${ }^{3}$ Hans $v$ Louisiana, 134 US 1, 10 (1890). The principle assumed to be behind the amendment has also been held to bar suits brought against states by foreign countries, Principality of Monaco v Mississippi, 292 US 313 (1934), and suits brought against states in admiralty, Ex parte New York (No. 1), 256 US 490 (1921).

4 Ex parte Young, 209 US 123 (1908); Edelman v Jordan, 415 US at 651. The Court has recently held that the power under Ex parte Young to order prospective relief extends only to federal law claims. Pennhurst State School and Hospital v Halderman, 465 US 89, 106 (1984).

S Pennsylvania v Union Gas Co., $109 \mathrm{~S} \mathrm{Ct}$ at 2273. 
tary appearance by the state. ${ }^{6}$

Beginning with Professor Martha Field in $1978,{ }^{7}$ a number of legal academics challenged the traditional view of the amendment. ${ }^{8}$ Now, a little more than a decade later, a new view of what the amendment was originally intended to accomplish has gained significant acceptance in the academic community ${ }^{9}$ and on the Court. The new view has been called, in shorthand fashion, the "diversity theory."10 Given the significant policy and doctrinal consequences that might result from a new understanding of the amendment's original meaning, and given the normal academic sport of challeng-

- Gunter $v$ Atlantic Coast Line Railroad Company, 200 US 273, 284 (1906); Clark v Barnard, 108 US 436, 447-48 (1883). Subdivisions of states, such as counties and municipalities, are not. protected by the amendment. Lincoln County $v$ Luning, 133 US 529, 530 (1890); Workman v New York City, 179 US 552, 565 (1900). Further, the United States Supreme Court may hear appeals of suits brought against the states in state court. Cohens $v$ Virginia, 19 US (6 Wheat) 264 (1821).

${ }^{7}$ Martha A. Field, The Eleventh Amendment and Other Sovereign Immunity Doctrines: Part One, $126 \mathrm{U}$ Pa L Rev 515 (1978) ("Field I"); Martha A. Field, The Eleventh Amendment and Other Sovereign Immunity Doctrines: Congressional Imposition of Suit Upon the States, 126 U Pa L Rev 1203 (1978) ("Field II").

- William A. Fletcher, A Historical Interpretation of the Eleventh Amendment: A Narrow Construction of an Affirmative Grant of Jurisdiction Rather than a Prohibition Against Jurisdiction, 35 Stan L Rev 1033 (1983); John J. Gibbons, The Eleventh Amendment and State Sovereign Immunity: A Reinterpretation, 83 Colum L Rev 1889 (1983); Akhil Reed Amar, Of Sovereignty and Federalism, 96 Yale L J 1425 (1987); and Vicki C. Jackson, The Supreme Court, the Eleventh Amendment, and State Sovereign Immunity, 98 Yale L J 1 (1988). In addition, Professor Nowak has argued in favor of a theory of Congressional abrogation. John E. Nowak, The Scope of Congressional Power to Create Causes of Action Against State Governments and the History of the Eleventh and Fourteenth Amendments, 75 Colum L Rev 1413 (1975). While Professor Nowak's historical thesis has not gained wide acceptance, I have found much of his original research very helpful. See also Laurence H. Tribe, Intergovernmental Immunities in Litigation, Taxation, and Regulation: Separation of Powers Issues in Controversies About Federalism, 89 Harv L Rev 682, 693-700 (1976) (arguing in favor of Congressional abrogation).

see the following comments on the new view: Erwin Chemerinsky, State Sovereignty and Federal Court Power: The Eleventh Amendment after Pennhurst v. Halderman, 12 Hastings Const L Q 643, 652 (1985) ("persuasively developed" view); Allen K. Easley, The Supreme Court and the Eleventh Amendment: Mourning the Lost Opportunity to Synthesize Conflicting Precedents, 64 Denver U L Rev 485, 488 (1988) ("conclusion makes sense"); H. Stephen Harris, Jr. and Michael P. Kenny, Eleventh Amendment Jurisprudence after Atascadero: The Coming Clash with Antitrust, Copyright, and Other Causes of Action Over Which the Federal Courts Have Exclusive Jurisdiction, 37 Emory L J 645, 654 (1988) ("persuasive" and "cogent" argument); David L. Shapiro, Wrong Turns: The Eleventh Amendment and the Pennhurst"Case, 98 Harv L Rev 61, 68 (1984) ("fully persuasive"); Keith Werhan, Pullman Abstention after Pennhurst: A Comment on Judicial Federalism, 27 Wm \& Mary L Rev 449, 460 n 46 (1986) ("a more sophisticated reading of the Eleventh Amendment"); and Laurence H. Tribe, American Constitutional Law 175 n 8 (Foundation, 2d ed 1988) ("a powerful argument").

10 William P. Marshall, The Diversity Theory of the Eleventh Amendment: A Critical Evaluation, 102 Harv L Rev 1372, 1373 (1989). 
ing the received (or, in this case, the almost received) wisdom, it is not surprising that the new view has itself come under attack.

In this essay I defend the most plausible version of the "diversity explanation" against three recent attacks. ${ }^{11}$ ("Explanation" seems to me a more appropriate term than "theory." Seeking a historical understanding of the Eleventh Amendment is not a particularly theoretical enterprise. As I view it, the task is to arrive at the best explanation of what the adopters intended, based on the known historical facts and the reasonable inferences that can be drawn from them.) Not surprisingly, the version of the diversity explanation that I defend is very similar to that which I elaborated several years ago.12 But the work of later scholars has induced me to modify my opinions on a few points, and in some instances where I have not changed my opinions, the work of others has added new support to my original view.

Everyone agrees that the Eleventh Amendment was adopted to overturn the result the Supreme Court reached in Chisholm $v$ Georgia $^{13}$ in 1793. The plaintiff in Chisholm was a citizen of South Carolina who had sued the state of Georgia on a contract in a common law assumpsit action. The suit was brought in the original jurisdiction of the Supreme Court. The source of jurisdiction was the provision in Article III of the United States Constitution extending the federal judicial power to "controversies ... between a State and Citizens of another State,"14 and a possibly unnecessary parallel provision in $\S 13$ of the Judiciary Act of $1789 .{ }^{15}$ The Supreme Court in Chisholm construed the Article III provision to mean that it had jurisdiction to hear Chisholm's damage action against Georgia, and held by a four to one vote that any sovereign immunity defense the state might otherwise have had was thereby

11 Calvin R. Massey, State Sovereignty and the Tenth and Eleventh Amendments, 56 U Chi L Rev 61 (1989); Lawrence C. Marshall, Fighting the Words of the Eleventh Amendment, 102 Harv L Rev 1342 (1989); and W. Marshall, 102 Harv L Rev at 1372 (cited in note 10).

12 Fletcher, 35 Stan L Rev at 1033 (cited in note 8).

132 US (2 Dall) 419 (1793). An excellent historical description of the case is in Doyle Mathis, Chisholm v. Georgia: Background and Settlement, $54 \mathrm{~J}$ Am Hist 19 (1967). An excellent history of the case in a larger context is in Clyde Edward Jacobs, The Eleventh Amendment and Sovereign Immunity (Greenwood, 1972). In addition, historical analysis specifically supporting the diversity explanation is in Amar, 96 Yale $L J$ at 1430 (cited in note 8); Field I, $126 \mathrm{U} \mathrm{Pa}$ L Rev at 515 (cited in note 7); Fletcher, 35 Stan L Rev at 1054 (cited in note 8); Gibbons, 83 Colum L Rev at 1920 (cited in note 8); and Jackson, 98 Yale L $J$ at 44-51 (cited in note 8). See also Nowak, 75 Colum L Rev at 1422 (cited in note 8), for historical analysis arguing for a theory of Congressional abrogation.

14 US Const, Art III, $\S 2$, cl 1.

${ }_{25}$ Judiciary Act of 1789 , ch $20, \S 13$, Stat 73,180 . 
abrogated. The Eleventh Amendment overruled the Court's decision in Chisholm, providing that "[t]he Judicial power of the United States shall not be construed to extend to any suit in law or equity, commenced or prosecuted against one of the United States by Citizens of another State, or by Citizens or Subjects of any Foreign State."16

Briefly stated, the diversity explanation is that the Eleventh Amendment was designed to overrule Chisholm by ehminating the state-citizen diversity jurisdiction from Article III. In more complicated but more precise terms, the amendment required tbat the state-citizen diversity clause be construed to authorize jurisdiction only when the state was a plaintiff; when the state was a defendant, the clause was not to be construed to authorize jurisdiction. In the words of Chief Justice Marsball in Osborn v Bank of United States, the Eleventh Amendment "has its full effect, if the constitution be construed as it would have been construed, had the jurisdiction of the Court never been extended to suits brought against a State, by the citizens of another State, or by aliens." 17 So understood, the Eleventh Amendment was not intended to eliminate or restrict other heads of jurisdiction. If jurisdiction existed over a suit against a state under the admiralty jurisdiction or the federal question jurisdiction before the passage of the amendment, such jurisdiction continued to exist after its passage. There is substantial evidence to suggest that admiralty jurisdiction existed both before and after the adoption of the amendment. Whether federal question jurisdiction existed before the passage of the amendment was unclear, however, and perforce remained so after its passage.

\section{An Abbreviated Historical NarRative}

Before responding to the attacks on the diversity explanation, I will set out in abbreviated fasbion wbat I view as the most coherent narrative of the adoption of the Eleventh Amendment. The narrative is available piecemeal in greater detail in other accounts of the amendment, ${ }^{18}$ but it cannot be found in complete form in any one of them. The following narrative combines what I view as

${ }^{16}$ US Const, Amend XI.

1722 US (9 Wheat) 738, 857-58 (1824).

18 See particularly Jacobs, Eleventh Amendment at 3-74 (cited in note 13); Amar, 96 Yale $\mathrm{L} \mathrm{J}$ at 1466-75 (cited in note 8); Field I, $126 \mathrm{U} \mathrm{Pa} \mathrm{L} \mathrm{Rev} \mathrm{at} \mathrm{527-46} \mathrm{(cited} \mathrm{in} \mathrm{note} \mathrm{7);}$ Fletcher, 35 Stan L Rev at 1045-63 (cited in note 8); Gibbons, 83 Colum L Rev at 1895-1941 (cited in note 8); Jackson, 98 Yale $\mathrm{L} \mathrm{J}$ at 13-51 (cited in note 8); Mathis, $54 \mathrm{~J}$ Am Hist at 2029 (cited in note 13); and Nowak, 75 Colum L Rev at 1422-41 (cited in note 8). 
the best elements of those accounts.

\section{A. Adoption of the Amendment}

The story begins with the adoption of the Constitution, which assigned to the national government some of the powers that had been retained by the states under the Articles of Confederation. Among other things, the Constitution authorized a new system of national courts. Article III authorized the exercise of the federal judicial power under various heads of jurisdiction. These heads of jurisdiction were of two kinds. First, some Article III provisions conferred jurisdiction over certain subject matters. For example, the federal courts were given jurisdiction over maritime cases and over cases arising under federal law. ${ }^{19}$ Second, some Article III provisions conferred jurisdiction because of the character of the parties. For example, the federal courts were given jurisdiction over suits between citizens of different states. ${ }^{20}$ Two heads of this second type gave the federal courts jurisdiction over suits between states and citizens of different states, and between states and citizens or subjects of foreign states. ${ }^{21}$ These last two heads of jurisdiction, which I will refer to as "state-citizen diversity" jurisdiction, are critical to the story of the Eleventh Amendment.

There was some discussion of state-citizen diversity jurisdiction during the state ratification debates on the proposed Constitution. ${ }^{22}$ As one would expect, those who opposed the adoption of the Constitution argued that state-citizen diversity jurisdiction would subject the states to unconsented suits in violation of their sovereignty. For example, during the Virginia debates George Mason pointed with alarm to anticipated litigation concerning disputed land claims in western Virginia: "Let gentlemen look at the westward. Claims respecting those lands, every liquidated account, or

19 US Const, Art III, § 2, cl 1 ("The judicial Power shall extend to all Cases, in Law and Equity, arising under this Constitution, the Laws of the United States, and Treaties made, or which shall be made, under their Authority; ... to all Cases of admiralty and maritime Jurisdiction . . . "). See also 28 USC $\S 1331$ (1982) (federal question jurisdiction) and $\S$ 1333 (1982) (admiralty jurisdiction).

20 US Const, Art III, § 2, cl 1 ("The judicial Power shall extend ... to Controversies ... between Citizens of different States . . . ."). See also 28 USC $\$ 1332$ (1982).

${ }^{21}$ US Const, Art III, $\$ 2$, cl 1 ("The judicial Power shall extend ... to Controversies ... between a State and Citizens of another State; ... and between a State . . . and foreign . . . Citizens or Subjects.").

${ }^{22}$ Description of the discussion is in Jacobs, Eleventh Amendment at 27-40 (cited in note 13); Field I, $126 \mathrm{U} \mathrm{Pa} \mathrm{L} \mathrm{Rev} \mathrm{at} \mathrm{527-36} \mathrm{(cited} \mathrm{in} \mathrm{note} \mathrm{7);} \mathrm{Fletcher,} 35$ Stan L Rev at 1045-54 (cited in note 8); Gibbons, 83 Colum L Rev at 1902-14 (cited in note 8); and Nowak, 75 Colum L Rev at 1423-30 (cited in note 8). 
other claim against this state, will be tried before the federal court. Is not this disgraceful?"23 The anti-Federalist, "Brutus," wrote in the New York Journal,

I conceive the [state-citizen diversity] clause . . improper in itself, and will, in its exercise, prove most pernicious and destructive. It is improper, because it subjects a state to answer in a court of law, to the suit of an individual ... . Every state in the union is largely indebted to individuals ..... If the power of the judicial under this clause will extend to the cases above stated, it will, if executed, produce the utmost confusion, and in its progress, will crush the states beneath its weight. And if it does not extend to these cases, I confess myself utterly at a loss to give it any meaning. ${ }^{24}$

The response of the Constitution's supporters was divided. Some argued that the clause would subject the states to suit, and that this was a point in its favor. For example, Edmund Randolph in Virginia argued that the clause would "render valid and effective existing claims, and secure that justice, ultimately, which is to be found in every regular government." ${ }^{25}$ Others contended that the clause would not subject the states to suit. For example, both John Marshall and James Madison in Virginia contended that it should be construed as conferring jurisdiction only when the state was a plaintiff, bringing suit against an out-of-state citizen; when the state was a defendant, sued by an out-of-state plaintiff, the clause would have no effect. ${ }^{26}$ Without fully explaining the basis

23 Jonathan Elliot, ed, 3 The Debates in the Several State Conventions on the Adoption of the Federal Constitution 526-27 (J. B. Lippincott, 1901) ("Elliot's Debates").

${ }_{24}$ Essays of Brutus, in Herbert J. Storing, ed, 2 The Complete Anti-Federalist 358, 429-31 (U Chicago, 1981); William Jeffrey, Jr., The Letters of "Brutus"-A Neglected Element in the Ratification Campaign of 1787-88, $40 \mathrm{U}$ Cin L Rev 643, 754-57 (1971).

${ }^{25} 3$ Elliot's Debates at 573 (cited in note 23 ).

${ }^{28}$ Madison argued:

Its jurisdiction in controversies between a state and citizens of another state is much objected to, and perhaps without reason. It is not in the power of individuals to call any state into court. The only operation it can have, is that, if a state should wish to bring a suit against a citizen, it must be brought before the federal court. This will give satisfaction to individuals, as it will prevent citizens, on whom a state may have a claim, being dissatisfied with the state courts.

Id at 533 (emphasis added). Marshall argued:

I hope that no gentleman will think that a state will be called at the bar of the federal court. Is there no such case at present? Are there not many cases in which the legislature of Virginia is a party, and yet the state is not sued? It is not rational to suppose that the sovereign power should be dragged before a court. The intent is, to enable states to recover claims of individuals residing in other states. I contend this construction is warranted by the words. But, say they, there will be partiality in it if a state 
for his conclusion, Alexander Hamilton in New York argued in Federalist 81 that state public securities issued to finance the Revolution could not be enforced in federal court, even if assigned to out-of-state citizens. ${ }^{27}$

Many of the state ratifying conventions approved the new Constitution only with the understanding that certain amendments would be made. Among the amendments proposed by Virginia, North Carolina, and Rhode Island was one that would have eliminated the state-citizen diversity jurisdiction. ${ }^{28}$ An identical amendment was proposed to the ratifying convention in New York but was not approved. ${ }^{29}$ Massachusetts and New Hampshire proposed a similar (or perhaps identical) amendment, but the text of the proposals has not been preserved..$^{30}$ During the first Congress, many of the amendments proposed by the state conventions were introduced, ultimately resulting in the adoption of the Bill of Rights. Representative Thomas Tucker of South Carohna proposed an amendment that would have eliminated the state-citizen diversity jurisdiction, but the proposal failed to gain enough support to be referred to the full House. ${ }^{31}$

Section thirteen of the Judiciary Act of 1789 granted original jurisdiction to the Supreme Court in state-citizen diversity cases. ${ }^{32}$ So far as the record reveals, this section of the act was adopted

cannot be defendant-if an individual cannot proceed to obtain judgement against a state, though he may be sued by a state. It is necessary to be so, and cannot be avoided. I see a difficulty in making a state defendant, which does not prevent its being plaintiff.

Id at 555-56 (emphasis added).

${ }^{27}$ Federalist 81 (Hamilton) in Clinton Rossiter, ed, The Federalist Papers 481, 487-88 (New Am Lib, 1961). Hamilton's comments were almost certainly intended to respond to "Brutus." See Fletcher, 35 Stan L Rev at 1047-48 n 63 (cited in note 8); and Jeffrey, 40 U Cin L Rev at 755 n 62 (cited in note 24). See also Gibbons, 83 Colum L Rev at 1910-11 (cited in note 8).

28 3 Elliot's Debates at 660-61 (Virginia) (cited in note 23); 4 Elliot's Debates at 246 (North Carolina); 2 Documentary History of the Constitution of the United States 317 (US Department of State, 1894) (Rhode Island). Rhode Island's proposal would also have explicitly forbidden suits for the payment of a state's public securities. Id.

292 Elliot's Debates at 207, 409 (cited in notc 23).

${ }^{30}$ St. George Tucker, 1 Blackstone's Commentaries: with Notes of Reference, to the Constitution and Laws, of the Federal Government of the United States; and the Commonwealth of Virginia 352 and $\mathrm{n}$ * (Birch and Small, 1803) ("Tucker's Blackstone").

311 Annals of Congress 791-92 (Aug 18, 1789), discussed in Fletcher, 35 Stan L Rev at 1052-53 (cited in note 8).

32 "[T]he Supreme Court shall have exclusive jurisdiction of all controversies of a civil nature, where a state is a party, except between a state and its citizens; and except also between a state and citizens of other states, or aliens, in which latter case it shall have original but not exclusive jurisdiction." Judiciary Act of 1789 , ch $20, \S 13,1$ Stat 73,80 . 
without discussion. ${ }^{33}$ Section nine of the Judiciary Act conferred original admiralty jurisdiction on the district courts. ${ }^{34}$ The Judiciary Act did not confer original federal question jurisdiction, however. ${ }^{35}$ The only federal question jurisdiction was conferred by $\S 25$, which gave the Supreme Court appellate jurisdiction over decisions by the state courts where a federal question had been raised and decided adversely to the federal right asserted. ${ }^{36}$

Chisholm $v$ Georgia ${ }^{37}$ was brought under the state-citizen diversity clause of Article III and $\S 13$ of the Judiciary Act. The suit was based on an asserted debt owed by the state of Georgia to a South Carolina merchant, Robert Farquhar, on a contract under which Farquhar had provided supplies to Georgia during the Revolution. At Farquhar's death, the debt was not paid. His executor, Chisholin, eventually filed suit in assumpsit in the Supreme Court, relying on state-citizen diversity. Chisholm did not assert a Contracts Clause claim or any other federal claim of right.

The Supreme Court held, four to one, that Georgia could be required to appear to defend the suit. Chief Justice Jay and Justices Blair, Cushing, and Wilson agreed that an action of assumpsit would lie against the state of Georgia under the Court's state-citizen diversity jurisdiction..$^{38}$ None of the four justices discussed the statutory conferral of that jurisdiction in $\S 13$ of the Judiciary Act. It is not clear whether they thought $\S 13$ so plainly conferred jurisdiction that discussion was unnecessary, or whether they thought the constitutional authorization of Article III self-executing, and $\S 13$ therefore superfluous.

Justice Iredell dissented, focusing on the state-citizen diversity jurisdiction conferred by $\S 13^{39}$ That section conferred "original but not exclusive" jurisdiction in state-citizen diversity cases. ${ }^{40}$ According to Iredell, this language meant that the Supreme Court had concurrent jurisdiction with the state of Georgia, and consequently that the Supreme Court could take jurisdiction of an as-

${ }^{33}$ Fletcher, 35 Stan L Rev at 1053-54 (cited in note 8).

${ }_{34}$ Judiciary Act of 1789 , ch $20, \S 9,1$ Stat $73,76-77$.

3s The Federalist-dominated Congress did pass a general original federal question jurisdictional statute in 1801, hut it was repealed the following year after the Jeffersonians gained control. Act of February 13,1801, ch 4, $\$ 11,2$ Stat 89, 92, repealed by Act of March 8,1802 , ch $8, \S 1,2$ Stat 132 . A new general original federal question jurisdictional statute was finally passed in 1875 . Act of March 3,1875 , ch $137, \S 1,18$ Stat 470 .

${ }^{36}$ Judiciary Act of 1789 , ch $20, \S 25,1$ Stat $73,85-87$.

372 US (2 Dall) 419 (1793).

${ }^{38}$ Id at *479 (Jay), *452 (Blair), *469 (Cushing) and *466 (Wilson).

${ }^{30}$ Id at *429 (Iredell dissenting).

40 Id at * 431 . 
sumpsit case against the state only if Georgia would take jurisdiction of such a case. ${ }^{41}$ Since the state courts of Georgia would not take jurisdiction, the jurisdiction could not be "concurrent," and therefore the Supreme Court could not hear the case under $\S 13 .{ }^{42}$ Justice Iredell declined to answer the question whether the Supreme Court could take jurisdiction over a case based on a federal statute specifically conferring jurisdiction, where Congress deemed such a law "necessary and proper to carry the purposes of this constitution into full effect."4s Iredell noted, however, that he had strong doubts about the constitutional power of Congress ever to authorize unconsented suits against a state "for the recovery of money," since "every word in the constitution may have its full effect, without involving this consequence."44

On February 19, 1793, one day after the Court announced its decision in Chisholm, Representative Theodore Sedgwick of Massachusetts introduced a proposed amendment in the House that would have fiatly prohibited a state from being made a defendant in a suit brought by a private individual:

That no state shall be liable to be made a party defendant in any of the judicial courts, established, or which shall be estabhished under the authority of the United States, at the suit of any person or persons whether a citizen or citizens, or a foreigner or foreigners, of any body politic or corporate, whether within or without the United States. ${ }^{45}$

\footnotetext{
11 Id at *436-37.

42 Id at * $437-49$.

4s Id at * $432, * 436$.

14 Id at *449-50.
}

4s Pennsylvania Journal and Weekly Advertiser 1, col 2 (Feb 27, 1793). Judge Gibbons doubts the existence of Sedgwick's proposed amendment because there is no record of it in the Annals of Congress, and because he has been unable to find any evidence of it in the National Archives. Gibbons, 83 Colum L Rev at 1926 n 186 (cited in note 8). Charles Warren quotes Sedgwick's proposed amendment without giving either Sedgwick's name or a source. Charles Warren, 1 The Supreme Court in United States History 101 (Little, Brown, 1923). Professor Nowak quotes the amendment, crediting Representative Sedgwick, and citing the Pennsylvania Journal of February 20, 1793. Nowak, 75 Colum L Rev at 1436 n 132 (cited in note 8). (I have heen unable to locate the Pennsylvania Journal, but have confirmed the information in the Pennsylvania Journal and Weekly Advertiser of February 27, 1793. It is possible that Professor Nowak's citation is shghtly mistaken, and that we are citing the same source.)

I have little doubt that Sedgwick introduced the proposed amendment. The Pennsylvania Journal and Weekly Advertiser, published "every Wednesday," contained a day-by-day record of the proceedings in Congress. As part of its entry for the House of Representatives for Tuesday, February 19, it recounts the following:

Mr. Sedgwick, after some introductory observations relative to a decision of the Judges of the Supreme Court, made yesterday, respecting the liability of states to be sued by 
The next day a different proposal was introduced in the House by a representative whose name has not come down to us. Unlike Sedgwick's proposal, this one focused only on out-of-state citizens and foreigners, paralleling the state-citizen jurisdiction of Article III:

The Judicial power of the United States shall not extend to any suits in law or equity, commenced or prosecuted against one of the United States by citizens of another State, or by citizens or subjects of any foreign State. ${ }^{46}$

Congress adjourned less than a month later without acting on either proposal.

When Congress reconvened almost a year later, the text of what would become the Eleventh Amendment was introduced in the Senate by an unknown senator on January 2, 1794:

The Judicial power of the United States shall not be construed to extend to any suit[] in law or equity, commenced or prosecuted against one of the United States by citizens of another State, or by citizens or subjects of any foreign State. ${ }^{47}$

The addition of the italicized words "be construed to" may be understood as clarifying the amendment. The second version, introduced in the prior session, had narrowed the focus of the amendment to the state-citizen diversity jurisdiction. This third version made the focus even more precise by specifying that the amendment was designed to correct a misconstruction of the state-citizen diversity clause in Chisholm. That is, the amendment made it clear that the clause had originally meant what Marshall and Madison

individuals, and which decision is affirmative of that idea-made the following motion, viz.

Resolved, by the Senate and House of Representatives of the United States of America, in Congress assembled, two thirds of both Houses concurring, that the following article be proposed to the legislatures of the several states, as an amendment of the Constitution of the United States, which, when ratified by three fourths of the said legislatures, shall be valid to all intents and purposes, as parts of the said Constitution, viz.

That no state shall be liable to be made a party defendant, in any of the judicial courts, established, or which shall be established under the authority of the United States, at the suit of any person or persons whether a citizen or citizens, or a foreigner or foreigners, of any body politic or corporate, whether within or without the United States-laid on the table.

Pennsylvania Journal and Weekly Advertiser 1, col 2 (Feb 27, 1793).

${ }^{16} 3$ Annals of Congress 651-52 (Feb 20, 1793).

174 Annals of Congress 25 (Jan 2,1794 ) (emphasis indicates words added to the previous version; the bracket indicates an "s" omitted from the previous version). 
had contended it meant, and that it was not to be construed otherwise.

Two further modifications were proposed in the Senate, ${ }^{48}$ one of which will be discussed in detail below. ${ }^{49}$ Both were defeated. ${ }^{50}$ One further modification was proposed, and defeated, in the House. ${ }^{51}$ The amendment was approved by the Senate in January, 1794, by the House in March, ${ }^{52}$ and by early 1795 had been ratified by the requisite three-quarters majority of the states..$^{53}$

\section{B. Meaning of the Amendment}

The adopters of the amendment were concerned with the possibility of monetary judgments against the states. At that time, such judgments were likely in tbree kinds of cases: private contract suits against the states, primarily based on the public securities of the states; suits disputing land titles, particularly in Virginia and Georgia; and suits by British citizens under the peace treaty of 1783.

Chisholm was an example of the first kind of case, a suit on a common law cause of action arising out of a contract. In a sense, Chisholm was uncharacteristic of this kind of suit, for it was based on an ordinary contract. The overwhelming majority of likely suits were based on public securities issued by the states during the Revolution. Such securities were of great concern to the states, as indicated by Brutus's coinment in the New York Journal. ${ }^{54}$ They were largely held by out-of-state citizens and foreigners who had bought them as speculators, at prices greatly below face value. ${ }^{55}$ In

48 First, Senator Albert Gallatin of Pennsylvania proposed a revision tbat would have excepted from the operation of the amendment causes of action to enforce treaties. Second, an unknown senator proposed a revision that would have confined the operation of the amendment to causes of action arising after its ratification. 4 Annals of Congress 30-31 (Jan $14,1794)$.

40 See text at notes 121-31 for discussion of the Gallatin proposal.

Bo 4 Annals of Congress 30 (Jan 14, 1794).

61 The proposed revision would have confined the operation of the amendment to suits brought against states tbat had already "made provision in their own Courts, whereby such suit may be prosecuted to effect." Id at 476 (March 4, 1794). That is, Chisholm would have been overridden only when the state courts were opened to the cleims that were eliminated by the Eleventh Amendment.

62 Id at 477.

${ }^{53}$ Jacobs, Eleventh Amendment at 67 (cited in note 13).

s4 See text at note 24 .

ss Warren, The Supreme Court at 99 (cited in note 45); William G. Anderson, The Price of Liberty: The Public Debt of the American Revolution 25 (U Virginia, 1983); E. James Ferguson, The Power of the Purse 270-72, 341 (U North Carolina, 1961). I am indebted to Professor Lawrence Marshall for emphasizing the threat that the public securities 
the legal sense that is critical here, however, ordinary contract suits like Chisholm and public securities suits were identical: both were based on common law rather than upon federal law. That is, neither suit could have been brought under federal question jurisdiction in the federal courts, even if such jurisdiction had been conferred by statute.

There were two suits of the second kind, involving land title disputes, pending in the Supreme Court when Chisholm was decided: Hollingsworth $v$ Virginia ${ }^{56}$ and Moultrie $v$ Georgia. ${ }^{57}$ Hollingsworth arose out of the land dispute that had concerned George Mason during the ratification debates in Virginia. Several Indian tribes had conveyed three million acres of land to the Indiana Company in 1768, and the Crown liad approved the conveyance. ${ }^{58}$ The Virginia legislature disapproved the grant in 1779 , and declared the land to be part of the public domain. Shareholders of the Indiana Company, most of whom were citizens of Pennsylvania, filed suit in the Supreme Court in $1792 .{ }^{59}$ Moultrie arose out of a contract under which Georgia agreed in 1789 to sell nearly 16 million acres of land to several land companies. Before the payment came due, the Georgia legislature passed a resolution requiring payment in specie. After one of the companies was unable to make payment on those terms, Georgia treated the contract as no longer binding and sold the land to another company. ${ }^{60} \mathrm{It}$ is unclear whether Hollingsworth ever involved a federal claim of riglit, or whether Moultrie was thought to involve a federal claim at the time the Eleventli Amendment was adopted..$^{61}$

cases presented to the states. L. Marshall, 102 Harv L Rev at 1364-66 (cited in note 11).

${ }^{88}$ Grayson $v$ Virginia, 3 US (3 Dall) *320 (1796), dismissed as Hollingsworth $v$ Virginia, 3 US ( 3 Dall) *378 (1798).

${ }^{87}$ Unreported, discussed in Jacobs, Eleventh Amendment at 63-64 and n 83 (cited in note 13).

s8 Id at 57-58; Gibbons, 83 Colum L Rev at 1904 (cited in note 8).

59 Jacobs, Eleventh Amendment at 57-58 (cited in note 13).

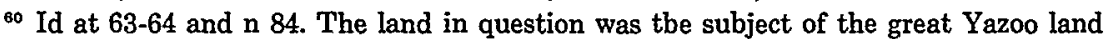
fraud, and later came before the Supreme Court under a subsequent contract to different purchasers in Fletcher v Peck, 10 US (6 Cranch) 87 (1810). See C. Peter MaGrath, Yazoo: Land and Politics in the New Republic 101 (Brown U, 1966).

B1 The state confiscation challenged in Hollingsworth took place in 1779 , before the adoption of the Constitution. The state action in Moultrie all took place after the adoption of the Constitution. Although the Supreme Court eventually decided in Fletcher v Peck, 10 US at 87, that a state would violate the Contract Clause (US Const, Art I, $\S 10, \mathrm{cl} 1$ ) by legislative repudiation of a contract with a private individual, Professor Wright argues that the clause was originally understood to protect only contracts between private parties from impairment by the states. Benjamin Fletcher Wright, Jr., The Contract Clause of the Constitution 15-21 (Harvard, 1938). 
The third kind of suit involved claims under the peace treaty with Great Britain. ${ }^{62}$ The treaty prohibited the states from imposing impediments to the recovery of outstanding debts, and prohibited future escheats of British and loyalist property. ${ }^{63}$ Claims against the states under the treaty involved enormous amounts of money, sought by loyalists and British subjects, at a time when political tension with Britain was high. ${ }^{64}$ Vassall $v$ Massachusetts, ${ }^{65}$ a claim by a loyalist whose property had been confiscated, was filed a few months after the Court's decision in Chisholm. ${ }^{66}$ We may assume that suits against states seeking recovery of debts and challenging escheats of property would have been federal question suits under Article III since they were brought pursuant to a treaty. ${ }^{67}$

With these suits in the background, what are we to make of the text of the amendment? Some of the suits involved only common law; some possibly involved federal law; and some almost certainly involved federal law. Ordinary contract suits-of which Chisholm is an example-were based on general common law rather than federal law. Congress had no power to authorize the federal courts to hear suits like Chisholm under the federal question jurisdiction even if it had wished to do so. ${ }^{68}$ Land disputes

${ }^{62}$ Definitive Treaty of Peace Between the United States of America and his Brittanic Majesty, 8 Stat 80 (1783) ("Treaty of Paris"). For the provisional treaty see 8 Stat 54 (Nov 30,1782 ).

63 Gibbons, 83 Colum L Rev at 1899-1902 (cited in note 8); L. Marshall, 102 Harv L Rev at 1356-60 (cited in note 11); and Warren, 1 The Supreme Court at 99 (cited in note 45).

64 Gibbons, 83 Colum L Rev at 1927-30 (cited in note 8); L. Marsball, 102 Harv L Rev at 1358 (cited in note 11); and Nowak, 75 Colum L Rev at 1438-39 (cited in note 8).

${ }^{65}$ Unreported, discussed in Jacobs, Eleventh Amendment at 60-62 (cited in note 13); Julius Goebel, Jr., 1 History of the Supreme Court of the United States: Antecedents and Beginnings to 1801 734-35 (Macmillan, 1971).

${ }^{68}$ Process was served in June, 1793. Id at 734; L. Marshall, 102 Harv L Rev at 1357 n 62 (cited in note 11).

${ }^{67}$ Article III provides that the federal judicial power extends to cases arising under "the Laws of the United States, and Treaties made, or which shall be made, under their Authority." US Const, Art III, $\S 2$, cl 1 . The Treaty of Paris was entered into before the Constitution was adopted, but the language of Article III-"made, or which shall be made"-seems to include both existing and future treaties. The Treaty of Paris was signed "under the authority" of the "United States," by that name. Treaty of Paris, 8 Stat 54 (cited in note 62).

${ }^{68}$ There was some uncertainty in the early years about whether the law in diversity cases heard by the federal courts was federal law within the meaning of the Supremacy Clause. See, for example, 1 Tucker's Blackstone at 379-80 (cited in note 30); William A. Fletcher, The General Common Law and Section 34 of the Judiciary Act of 1789: The Example of Marine Insurance, 97 Harv L Rev 1513, 1521-27 (1984); and Stewart Jay, Origins of Federal Common Law: Part Two, $133 \mathrm{U}$ Pa L Rev 1231, 1255-67 (1985). But it was 
possibly involved federal law-and after Fletcher $v$ Peck $k^{69}$ in 1810 certainly would have involved federal law if based on a contract directly with the state. Finally, treaty-based suits involved federal law sufficient to support federal question jurisdiction in the federal courts.

There are two ways to understand what the adopters of the amendment intended. The first is to read the amendment as forbidding all suits against states by out-of-state citizens and foreign citizens or subjects. The second is to read the amendment as failing to authorize jurisdiction, by requiring a narrow construction of the affirmative grant of party-based jurisdiction; that is, after the amendment, the state-citizen diversity clause authorizes jurisdiction when a state is a plaintiff but not when it is a defendant. Under the first reading, there can be no federal court jurisdiction even if the suit is brought under federal question jurisdiction. Under the second reading, federal court jurisdiction exists whenever there is an implementing statute authorizing federal question jurisdiction and the suit satisfies the criteria of that head of jurisdiction. Under either reading of the amendment, admiralty jurisdiction is not forbidden, for the amendment refers only to suits "in law and equity." Thus, whether the language is read as "forbidding" or merely "failing to authorize," admiralty is not affected."

The second reading seems to me far more likely than the first. The state-citizen diversity clause of Article III authorized jurisdiction in all three kinds of cases in which monetary judgments were sought against the states; eliminating that clause from the Constitution required the dismissal of those cases. Since there was no

never thought that such common law, even if supreme federal law, was a basis for jurisdiction under federal question jurisdiction. See, for example, Peter S. Du Ponceau, A Dissertation on the Nature and Extent of the Jurisdiction of the Courts of the United States xiv$\mathrm{xv}$ (Small, 1824).

69 10 US (6 Cranch) 87 (1810).

70 The early case law seems to have understood the amendment as not affecting admiralty jurisdiction. Justice Washington, sitting on circuit, held that admiralty was unaffected. United States $v$ Bright, 24 F Cases 1232, 1234 (D Pa Cir, 1809). The Supreme Court avoided answering the question on three separate occasions. United States $v$ Peters, 9 US (5 Cranch) 115 (1809); Governor of Georgia v Madrazo, 26 US (1 Pet) *110 (1828); and Ex parte Madrazzo, 32 US (7 Pet) 627 (1833). Peter Du Ponceau and Joseph Story both read the amendment as not affecting admiralty. Peter S. Du Ponceau, A Brief View of the Constitution of the United States 37-38 (E.G. Dorsey, 1834); Joseph Story, 3 Commentaries on the Constitution of the United States 560-61 (Hilliard, Gray, 1833, reprinted Da Capo Press, 1970).

Professor Lawrence Marshall concedes that admiralty jurisdiction is not affected by the Eleventh Amendment. L. Marshall, 102 Harv L Rev at 1355 n 53 (cited in note 11). Neither Professor William Marshall nor Professor Massey discusses admiralty jurisdiction. 
original federal question jurisdiction statute, there was no other basis upon which they could be brought originally in federal court. Whether private suits against the states could have been authorized by a federal question statute was not, in my view, intended to be resolved by the Eleventh Amendment. A more detailed argument in favor of this reading of the amendment may be found in my earlier article, ${ }^{71}$ and arguments going in the same direction, indeed further, may be found in other articles. ${ }^{72}$ Additional (and somewhat selective) elaboration appears in my responses below to the three recent articles that attack this reading of the amendment.

\section{Response to Critics}

Two of the critics, Professors Lawrence Marshall and Calvin Massey, adopt variations on what may be termed a "plain language reading" of the amendment. In their view, the language of the amendment is very clear in its intent to forbid jurisdiction when an out-of-state citizen or a foreigu citizen or subject sues a state. They contend that none of the "revisionists" strated that this is such an implausible intent that we should abandon the meaning clearly manifested by the text of the amendment. I disagree with Professors Lawrence Marshall and Massey, both as to whether the text of the amendment has the clear meaning they impute to it, and as to what the amendment was intended to accomplish.

The third critic, Professor William Marshall, believes that the language of the amendment is not clear, but he argues that the "diversity theorists" that the adopters of the amendment specifically intended to leave unimpaired the federal question head of jurisdiction. I substantially agree with many of Professor William Marshall's arguments, but, as I will show, the diversity explanation is fully consistent with them.

71 Fletcher, 35 Stan L Rev at 1045-87 (cited in note 8).

72 See, Amar, 96 Yale L $J$ at 1466-92 (cited in note 8). Judge Gibbons states: "The immediacy of the foreign affairs crisis at the time of the drafting of the amendment and the related Federalist concern with enforcing the peace treaty makes clear that the amendment was not intended to remove from federal purview suits against states in which federal question jurisdiction had been invoked." Gibbons, 83 Colum L Rev at 1894 (cited in note 8 , emphasis in original).

73 Massey, $56 \mathrm{U}$ Chi L Rev at 62, 63-65 (cited in note 11).

74 W. Marsball, 102 Harv L Rev at 1373, 1395-96 (cited in note 10). 


\section{A. Response to Professors Lawrence Marshall and Massey}

1. The "plain meaning of the text."

Professor Lawrence Marshall has no doubt about what the text of the amendment means. At several places, he refers to the "plain meaning of the text," to the "essentially unambiguous dictates of the amendment's language," ity" of the amendment." According to Professor Lawrence Marshall, the plain meaning is that the "amendment precludes federal jurisdiction over 'any suit in law or equity commenced or prosecuted against one of the United States by Citizens of another State, or by Citizens or Subjects of any Foreign State.' Thus, even if an out-of-state citizen brings the case under the federal question head of jurisdiction, the suit is barred."78 Professor Massey is slightly less emphatic, but shares Professor Marshall's view of the import of the language. He proposes that we take the amendment's "text and the history of its enactment at face value," tends that those who argue for the diversity explanation of the amendment "are required to amend its text in order to deliver their desired meaning."80 Professor Massey claims that the "amendment sought to create a party-based denial of jurisdiction to the federal courts that sweeps across all the jurisdictional heads of Article III."\$1

The problem is that the text does not clearly mean what Professors Marshall and Massey think it does. Indeed, based on almost-contemporary usage, one can argue that the text is clear, but with the meaning for which the revisionists argue. On February 8, 1805, Senator Breckenridge of Kentucky introduced a proposed amendment to the Constitution that would have substantially limited the federal courts' jurisdiction. ${ }^{82}$ Breckenridge's amendment was not adopted; and it was proposed in each of the

76 L. Marshall, 102 Harv L Rev at 1371 (cited in note 11).

76 Id at 1343 .

77 Id at 1349.

${ }^{78}$ Id at 1346.

70 Massey, $56 \mathrm{U}$ Chi L Rev at 65 (cited in note 11).

so Id at 115 .

${ }^{81}$ Id at 65 (emphasis in original).

${ }_{82} 14$ Annals of Congress 53 (Feb 8, 1805). Senator Breckenridge was no neophyte at changing the jurisdictional structure of the federal courts. Three years earlier, he had introduced the legislation that repealed the short-lived original federal question jurisdiction created by the Federalists in 1801. Debates in the Congress of the United States, on the Bill for Repealing the Law "For the More Convenient Organization of the Courts of the United States" 5 (Whiting, Leavenworth \& Whiting, 1802). 
succeeding two years in the Congress, in substantially the same words, also without success. ${ }^{83}$ But its text tells us a great deal about the Eleventh Amendment. In its entirety, Breckenridge's proposed amendment read as follows: "The judicial power of the United States shall not be construed to extend to controversies between a State and citizens of another State, between citizens of different states, between citizens of the same State, claiming lands under grants of different States; and between a State or the citizens thereof and foreign States, citizens, or subjects."84

The wording of Breckenridge's amendment-"the judicial power shall not be construed to extend"-is identical to that of the Eleventh Amendment. ${ }^{85}$ Yet we know that the proposed amendment was not designed to prohibit federal question jurisdiction whenever the parties were aligned in the specified ways. I take as my example the citizen-citizen diversity jurisdiction, although the point could be made using any of the other specified heads of jurisdiction. ${ }^{86}$ The proposed amendment clearly intended a repeal of the citizen-citizen diversity jurisdiction rather than a prohibition of federal court jurisdiction whenever a citizen of one state sued a citizen of another state. A strong argument in favor of this reading is based on reason and common sense. If we read the proposed amendment as prohibiting jurisdiction whenever a citizen of one state sued a citizen of another, we would have the unlikely, even impossible, result of federal question suits being barred whenever

ss 15 Annals of Congress 68 (Jan 22, 1806) (Senator Maclay of Pennsylvania); $16 \mathrm{An}$ nals of Congress 76 (Feb 20, 1807) (Senator Clay of Kentucky). I am grateful to Professors Amar and Massey for unearthing these proposed amendments, of whicb I was unaware when I wrote my earlier article. See Amar, 96 Yale L J at 1482-83 n 233 (cited in note 8); Massey, $56 \mathrm{U}$ Cbi L Rev 118 and $n 294$ (cited in note 11). I apologize for now using them, somewhat ungratefully, against Professor Massey.

s4 14 Annals of Congress 53 (Feb 8, 1805).

ss "The Judicial power of the United States shall not be construed to extend to any suit ...." US Const, Amend XI. Breckenridge's language omits the word "any," but I do not understand that omission to change the linguistic analysis. The prohibition on jurisdiction, if any, would result from the words "shall not be construed to extend." The argument for reading the amendment as a prohibition is essentially an argument stemming from the failure of the drafters to add words such as "when jurisdiction is based on party alignment." See, for example, Massey, $56 \mathrm{U}$ Chi L Rev at 115 (cited in note 11). Professor L. Marshall emphasizes the word "any" in arguing that tbe amendment prohibits jurisdiction, but thinks his reading proper "[e]ven without regard to the word 'any[.]" " L. Marshall, 102 Harv L Rev at 1347 (cited in note 11).

${ }^{86}$ Note that the first clause of Breckenridge's proposed amendment provided that the judicial power should not be construed to extend to "controversies between a State and citizens of another State." This clause would have fully repealed tbe state-citizen diversity clause. The Eleventh Amendment effectuated a repeal only in suits in which the states were defendants. 
the suit was between diverse citizens, and permitted whenever the suit was between citizens of the same state. In other words, federal question suits would have been confined to the state courts in precisely those instances where there was the most reason to distrust the state courts, and permitted in the federal courts when the state courts could be most trusted.

Fortunately, we are not left to rely solely on our reconstruction of the proposed amendment's reasonable intent. We have, in addition, a contemporaneous gloss. On December 26, 1806, Representative James Elliot of Vermont introduced a resolution supporting the proposed amendment. Elliot characterized the amendment as confining the federal courts' jurisdiction to federal question cases, suits in admiralty, and a few other categories of suits. ${ }^{87}$ Thus, Elliot's resolution makes clear that diversity as a basis for jurisdiction was to be eliminated, but that federal question jurisdiction was to be preserved in its entirety. ${ }^{88}$

Breckenridge's proposed amendment is, to our ear, linguistically deficient in the same way as the Eleventh Amendment. If I were writing the proposed amendment or the Eleventh Amendment today, and wished them only to repeal the citizen-citizen or state-citizen diversity heads of jurisdiction, I would write them differently. For example, I would readily adopt language such as that proposed by either Professor Lawrence Marshall ${ }^{89}$ or Professor Massey, ${ }^{90}$ making explicit that federal jurisdiction over parties in

87 Elliot "presented to the House ... a resolution ... concurring with the resolutions of the State of Kentucky, proposing an amendment to the Constitution of the United States, 'for confining the judiciary power of the Courts of the United States to cases in law and equity, arising under the Constitution and laws of the United States, and treaties made, or which shall be made under their autbority; ... [and] cases of admiralty and maritime jurisdiction. ..." "16 Annals of Congress 216 (Dec 26, 1806).

${ }^{88}$ Professor Massey discusses Breckenridge's proposed amendment, and concedes that it is "anomalous" to read the Eleventb Amendment as prohibiting jurisdiction while reading Breckenridge's amendment as merely repealing a previous grant of jurisdiction. Massey, 56 U Chi L Rev at 118 (cited in note 11). Professor Marshall does not mention the proposed amendment. L. Marshall, 102 Harv L Rev at 1342 (cited in note 11).

89 "There would surely be no arguments today had the amendment provided: "The clauses of the Constitution extending the judicial power to controversies between a state and citizens of anotber state, and between a state and foreign citizens or subjects, shall not be construed to extend to any suit in law or equity, commenced or prosecuted against one of the United States.' Dozens of other straightforward ways of conveying this message also come to mind." L. Marshall, 102 Harv L Rev at 1347 n 21 (cited in note 11).

so "In revisionist parlance, the Eleventh Amendment reads: The Judicial power of the United States shall not be construed to extend to any suit in law or equity founded upon $a$ diverse party head of jurisdiction, commenced or prosecuted against one of the United States by Citizens of another State, or by Citizens or Subjects of any Foreigu State." Massey, $56 \mathrm{U}$ Cbi L Rev at 115 (cited in note 11) (emphasis in original). 
the specified alignment is not available when jurisdiction is based on the character of the parties. The omission of the italicized words, or words to that effect, indicates to the modern reader (or at least to Professors Marshall and Massey) that jurisdiction is not available when the parties are so aligned, even if some other head of jurisdiction is available. Yet, as the Breckenridge amendment proposed in 1805, 1806, and 1807 makes clear, the omission of these words was understood at the time as no more than an ellipsis.

2. Professor Lawrence Marshall's non-textual argument against the diversity explanation.

Professor Lawrence Marshall's argument proceeds in two steps. First, as noted above, he contends that the plain meaning of the amendment prohibits federal court jurisdiction whenever an out-of-state or foreign citizen sues a state. Second, he uses the clarity of the amendment's text as a sort of standard-of-proof argument, contending that "there are plausible explanations for why the amendment reads as it does, and that there is, therefore, no justification for discarding the plain meaning of the text." already shown that, at the very least, the text of the amendment is not clear. Indeed, I think I have shown that the text is moderately clear, but with a meaning that supports the diversity explanation rather than Professor Lawrence Marshall's explanation. If we understand the text as supporting the diversity explanation, Professor Lawrence Marshall must show that the reasons supporting his reading are compelling rather than merely plausible, for he is arguing against rather than with the grain. But I think that Professor Lawrence Marshall has not succeeded even in the task he set out for himself. ${ }^{92}$

At a general level, I agree fully with Professor Lawrence Marshall. He argues that it is "unnecessary and inappropriate" to seek to explain the Eleventh Amendment by "one value" that it implements, or by a "single theoretical principle." ${ }^{93} \mathrm{He}$ urges that we

91 L. Marshall, 102 Harv L Rev at 1371 (cited in note 11) (emphasis in original).

${ }_{82}$ Professor William Marshall agrees that Professor Lawrence Marshall has not established persuasive reasons for his reading of the amendment. He states that Professor Lawrence Marshall "valiantly attempts to make sense of the literal language of the eleventh amendment," but "there is no persuasive reason why suits based upon federal law should be allowed in federal court when brought by an in-stater, but should not be allowed in federal court when brought by an out-of-stater." W. Marshall, 102 Harv L Rev at 1378 and n 44 (cited in note 10).

${ }^{93}$ L. Marshall, 102 Harv L Rev at 1353 (cited in note 11) (emphasis in original). 
understand the amendment as a "balance between the competing values of state immunity from federal suit and accountability to the new federal system" that is "consistent with the political and fiscal realities of the early and mid-1790's."94 This approach seems to me quite right. ${ }^{95}$ But after the general question is properly framed, the particular question remains: What was the balance that was actually struck by the amendment? It is in answering the particular question that Professor Lawrence Marshall has gone astray.

The linchpin of Professor Lawrence Marshall's argument is that it would have been rational for the adopters of the amendment to bar out-of-staters and foreigners from suing states in federal courts, even when suit was brought under federal law, and at the same time to permit in-staters to sue states in federal court under federal law. ${ }^{96}$ Professor Lawrence Marshall's argument in favor of this distinction rests on essentially two grounds.

a. Claims held by out-of-staters. First, Professor Lawrence Marshall points out that at the time of the amendment's adoption, out-of-staters held most of the obligations on which the states were likely to be sued, and argues that the adopters therefore cared most about forbidding suits by out-of-staters. ${ }^{97}$ It is true that most of the claims that worried the states were in the hands of out-ofstaters and foreigners, but this fact does not support Professor Lawrence Marshall's reading of the amendment. To understand the situation that faced the adopters, one must distinguish between claims brought under the common law or under state law, and claims brought under federal law.

Many of the claims held by out-of-staters were not based on federal law. This was clearly so for the private contract claim in Chisholm; it was probably so for the contract claims brought on the states' public securities, at least until a state legislature repudi-

94 Id at $1353,1355$.

95 Professor Lawrence Marshall contends that the "fallacy of the current eleventh amendment theories lies in their relentless demand for a single theoretical principle that can coherently explain the amendment." Id at 1353. I do not think that this is an accurate description of the diversity explanation of the amendment.

${ }_{\text {ss }}$ Professor Lawrence Marshall also argues that it would have been rational for the adopters of the amendment to distinguish between foreign citizens or subjects on the one hand, and foreign states on the other. L. Marshall, 102 Harv L Rev at 1356-62 (cited in note 11). The twentieth century Supreme Court assimilated foreign countries to foreigu citizens or subjects in Principality of Monaco v Mississippi, 292 US 313 (1934), but the distinction between the two is not at issue here. No one arguing for the diversity explanation argues against the distinction.

${ }^{97}$ L. Marshall, 102 Harv L Rev at 1362-71 (cited in note 11). 
ated the obligations; ${ }^{98}$ and it was probably so for the claims in the Indiana Land Company litigation in Hollingsworth $v$ Virginia. ${ }^{98}$ These claims, based on non-federal law, are at the heart of the diversity explanation. Since the only possible basis for federal court jurisdiction over them was the state-citizen diversity clause, eliminating that clause from the Constitution was a fully sufficient way of preventing the federal courts from hearing them. There was no need to prohibit the federal courts' jurisdiction, since there were no federal questions involved that could have provided an alternative basis for jurisdiction.

Claims held by out-of-staters or foreigners based on federal law were another matter. There were possibly a number of such claims. After the Court held in Fletcher $v$ Peck ${ }^{100}$ in 1810 that the Contract Clause extends to contracts in which a state is a party, both the public securities claims against the states and the land litigation in Moultrie $v$ Georgia ${ }^{101}$ would have involved claims under federal law. Whether they were seen as federal question cases at the time the amendment was adopted is unclear, but they may have been seen as potential federal claims. Claims under the 1783 peace treaty with Britain were almost certainly federal claims. All these claims were held in significant part by out-of-staters and foreigners, largely because of assignment by in-staters. Professor Lawrence Marshall contends that it would have been rational for the adopters of the amendment to forbid these claims when brought by out-of-staters and foreigners, but to permit them when brought by in-staters. But this can hardly have been rational if the states were concerned about the impact on their treasuries (as everyone, including Professor Lawrence Marshall, concedes they were), for those claims could easily have been assigned (or reassigned) to in-state citizens. ${ }^{102}$

Professor Lawrence Marshall acknowledges the difficulty posed by assignments, calling it a "perplexing problem." ${ }^{103}$ His initial response to the problem is to say that the "assignment ques-

${ }^{98}$ As discussed above, it was not clear in the 1790 s whether a state's repudiation of its own contract could constitute a violation of the Contract Clause. See note 61 .

"9 Grayson v Virginia, 3 US (3 Dall) *320 (1796), dismissed as Hollingsworth v Virginia, 3 US (3 Dall) *378 (1798).

${ }^{100} 10$ US (6 Cranch) 87, 137 (1810).

${ }^{101}$ Unreported, discussed in Jacobs, Eleventh Amendment at 63-64 and n 83 (cited in note 13).

${ }_{102}$ Professor William Marshall makes this point. W. Marshall, 102 Harv L Rev at 1379 n 44 (cited in note 10).

${ }^{103}$ L. Marshall, 102 Harv L Rev at 1367 n 113 (cited in note 11). 
tion plagues all readings of the amendment."104 It does not plague the diversity explanation, however. Assignment is a perplexing problem for Professor Lawrence Marshall because he needs to explain why the adopters would have gone to the trouble of prohibiting jurisdiction to protect state treasuries, while leaving open an obvious way to enforce the claims against the states. Under the diversity explanation, in-state and out-of-state citizens were treated equally. Federal question jurisdiction existed for out-ofstaters and in-staters alike. Thus, assignment of claims based on federal law was unnecessary, because no category of private claimant was forbidden to bring suit. ${ }^{105}$

Professor Lawrence Marshall also argues that the adopters of the amendment might have thought that the Court would invalidate assignments to in-staters. ${ }^{106} \mathrm{He}$ presents no evidence of contemporary understanding to support this view, and I know of none. Finally, Professor Lawrence Marshall minimizes the assignment difficulty by characterizing the possibility of assignment as a "small loophole[]."107 But it was not a small loophole. If assignment were possible, out-of-state speculators who had originally bought state securities from in-staters could, by the simple assignment of the claim back to an in-stater, transform a largely worthless piece of paper into a security redeemable at par. ${ }^{108} \mathrm{We}$ know that the adopters were aware that there had once been an interstate market in these securities, for this market had given rise to the very problem that worried them. ${ }^{109}$ We should assume that the adopters, in attempting to resolve the problem, would have taken into account the likelihood that there would be such a market again.

104 Id.

${ }_{105}$ The difficulty for the diversity explanation is quite different. It must argue that the adopters of the amendment would have left the states potentially vulnerable to suits under federal law by all private parties, not merely by assignees of the claims. Fletcher, $35 \mathrm{Stan} \mathrm{L}$ Rev at 1063-78 (cited in note 8); Gibbons, 83 Colum L Rev at 1899-1941 (cited in note 8). See also notes 158-61, 171-72, and accompanying text.

${ }^{108}$ L. Marshall, 102 Harv L Rev at 1367 n 113 (cited in note 11).

107 Id.

108 The ability to assign claims was never in question. I am unaware of any case in which the consequences of a bona fide assignment of a claim were avoided until Principality of Monaco $v$ Mississippi, 292 US 313 (1934). This was a twentieth century case, and the avoidance of the claim was not accomplished by invalidation of the assignment; rather, it was accomplished by expanding the prohibition of the amendment to foreign states.

109 L. Marshall, 102 Harv L Rev at 1365 n 107, 1367 n 113 (cited in note 11). Congress had understood that assignments could cause problems when it drafted the Judiciary Act of 1789, for the Act forbade using assignment to create citizen-citizen diversity jurisdiction. Judiciary Act of 1789 , ch $20, \S 11,1$ Stat 73, 78-79. 
b. Constitutional rights. Second, Professor Lawrence Marshall argues in favor of the distinction between in-staters and out-ofstaters on the ground that preserving federal question claims brought against states by in-staters, and by the United States and the individual states, protected the most important core of constitutional rights. ${ }^{110}$ Such an argument might be plausible if the amendment were adopted today, because of the constitutional rights that have been created pursuant to the post-Civil War settlement, but it can hardly be plausible for an amendment adopted in the 1790s. Many of the constitutional prohibitions against the states were directed at preventing the states from discriminating against out-of-staters. The Privileges and Immunities Clause is the most obvious example. ${ }^{111}$ Under Professor Lawrence Marshall's reading of the Eleventh Amendment, the adopters prohibited federal judicial redress of constitutional violations by the states that the national government was uniquely qualified to protect against. It seems to me exceedingly unlikely that someone in the late eighteenth century would have intended this result, and Professor Lawrence Marshall gives us no direct evidence to support his conclusion that this was, in fact, intended.12 Additionally, Professor Lawrence Marshall argues that the jurisdiction that remained over suits brought against states by the United States and by other states would have sufficed to protect against state constitutional violations such as coining money, entering into treaties, and violating the Contract Clause. ${ }^{113}$ But he makes no showing either that the United States and the states were thought to have causes of action to redress such violations, or that the adopters of the amendment had any such possibility in mind.

3. Professor Massey's non-textual argument against the diversity explanation.

It is difficult to decide how broadly to respond to Professor Massey's attack on the "revisionist" explanation of the Eleventh

110 L. Marshall, 102 Harv L Rev at 1367-68 (cited in note 11).

11 Professor Lawrence Marshall says only the following about the Privileges and Immunities Clause: "The creation of diversity jurisdiction and the privileges and immunities clause is evidence of the framers' understanding that the mere enactment of the Constitution would not erase the allegiances and prejudices that had long developed along state lines." L. Marshall, $102 \mathrm{Harv}$ L Rev at 1370 n 129 (cited in note 11).

${ }_{112}$ Professor William Marshall agrees. In his view, protecting the federal rights of instaters but not those of out-of-staters would have been "at best, ironic." W. Marshall, 102 Harv L Rev at 1378-79 n 44 (cited in note 10).

${ }^{113}$ L. Marshall, 102 Harv L Rev at 1368 (cited in note 11). 
Amendment. ${ }^{114} \mathrm{He}$ advances both an historical theory and a modern interpretation of the amendment, but is not entirely clear where one leaves off and the other begins. Professor Massey makes an historical argument that the amendment was intended to bar suits against states in federal courts when brought by out-of-staters or foreigners. ${ }^{116} \mathrm{He}$ also states that it is somewhat uncertain whether, as an historical matter, the adopters intended to prohibit or permit suits brought by in-staters. ${ }^{116} \mathrm{He}$ then arrives at a comprehensive reading of the amendment purportedly based on its history.

Under Professor Massey's view, the amendment's prohibition of all suits brought against a state by out-of-staters or foreigners is a constitutionally mandated denial of subject matter jurisdiction that the state cannot waive by appearance and that Congress cannot override by legislation. ${ }^{117}$ For in-staters, by contrast, there is no jurisdictional bar. Congress can authorize suits against states by in-state citizens, limited only by the Tenth Amendment. ${ }^{118}$ Professor Massey professes not to like this result, but argues that it is compelled by history:

A rule that permits the states to violate the federal rights of non-citizens and avoid direct accountability in federal court for those actions seems most peculiar, indeed, almost perverse. That, however, may be the legacy left by the 'unflinchingly political' decision to enact the Eleventh Amendment in order to avoid state liability to British creditors and to loyal-

114 Massey, 56 U Chi L Rev at 62-67 (cited in note 11).

115 "The amendment sought to create a party based denial of jurisdiction to the federal courts that sweeps across all the jurisdictional heads of Article III." Id at 65 (emphasis in original).

116 "Far less clear is whether the amendment was also intended to repudiate any implicit waiver of state sovereign immunity contained in the jurisdictional grants of Article III. If this more ambitious goal was contemplated, it is difficult to understand why it was not plainly stated, as Representative Sedgwick had initially proposed." Id at 119.

${ }_{117}$ Id at 66. The first of these two propositions is not consistent with modern law, and may never have been the law. Since at least Clark v Barnard, 108 US 436, 447-48 (1883), state consent to suit has waived any sovereign immunity-based jurisdictional defect in the federal courts. I suspect that the result in Clark would have been entirely acceptable in the 1790s, even to the adopters of the Eleventh Amendment. The difficulty with the result in Chisholm was precisely that the state had not consented to suit.

The second proposition is not consistent with modern law. See, for example, Fitzpatrick $v$ Bitzer, 427 US 445, 456 (1976) (Congress may abrogate the Eleventh Amendment when acting under the Fourteenth Amendment), and Pennsylvania v Union Gas, $109 \mathrm{~S} \mathrm{Ct}$ 2273 (1989) (Congress may abrogate the Eleventh Amendment when acting under the Commerce Clause).

${ }^{116}$ Id. 
ists seeking to reclaim their seized property. ${ }^{119}$

As I read the historical evidence presented in Professor Massey's article, I understand him to have concluded with certainty only that the adopters intended to prohibit suits by out-of-staters and foreigners. Thus, I will confine my historical argument to this point. In addition to the plain-meaning-of-the-text argument discussed earlier, ${ }^{120}$ Professor Massey advances three arguments in support of his conclusion.

a. The Gallatin proposal. First, Professor Massey points to language Senator Gallatin of Pennsylvania sought to add to the amendment. ${ }^{121}$ At the time of Gallatin's proposal, the amendment consisted of the text that eventually was adopted. Gallatin would have had the Eleventh Amendment read as follows (with his proposed language in italics): "The Judicial power of the United States, except in cases arising under treaties made under the authority of the United States, shall not be construed to extend to any suit in law or equity, commenced or prosecuted against one of the United States, by citizens of another State, or by citizens or subjects of any foreign State."122 Gallatin's proposal was overwhelmingly defeated. Professor Massey argues that it was defeated because it would have "permitted precisely the kind of action that debtor states wished to eliminate," and he relies on this to conclude that the amendment was intended to prohibit suits when brought by out-of-staters or foreigners. ${ }^{123} \mathrm{I}$ view this as Professor Massey's strongest argument, since he is clearly correct both in saying that states were significantly concerned by the possibility of claims based on the peace treaty with Britain, and in reading Gallatin's language as making clear that such treaty-based claims would be preserved.

Judge Gibbons has anticipated and responded to this argument. ${ }^{124}$ His view of the political situation is very much hike Professor Massey's. The Federalists wanted to assure Britain that the peace treaty provisions concerning recovery of escheated property would be enforceable, and Gallatin's amendment would have greatly assisted in this effort. ${ }^{125}$ The states were sufficiently con-

110 Id at 67 (footnote omitted).

120 See discussion in text at notes 79-90.

121 See note 48.

1224 Annals of Congress 30 (Jan 14, 1794) (emphasis indicates additional language proposed by Gallatin).

${ }^{123}$ Massey, 56 U Chi L Rev at 114 (cited in note 11).

124 Gibbons, 83 Colum $\mathrm{L} \mathrm{Rev}$ at 1932-38 (cited in note 8).

${ }_{125}$ The only mystery is why Gallatin made the motion. As Judge Gibbons points out, 
cerned about enforcement in cases such as Vassall $v$ Massachusetts, ${ }^{126}$ then pending in the Supreme Court, that they rejected Gallatin's amendment. But examine closely what they rejected. If we read the amendment as merely repealing party-based heads of jurisdiction, Gallatin's language would have had the effect of preserving that party-based jurisdiction when suit was brought on a treaty. In Judge Gibbons's words, Gallatin's language was rejected "because it would have left intact the Supreme Court's original jurisdiction over cases such as Vassall $v$ Massachusetts, a party-status suit that simultaneously raised a substantive federal question under the treaty." 127

Under this reading of the amendment, rejection of Gallatin's language meant rejection of party-based jurisdiction in treaty cases. Jurisdiction over treaty suits could still exist under federal question jurisdiction, however. Two possibilities existed after the adoption of the amendment. First, $\S 25$ of the Judiciary Act already provided for Supreme Court review of state court decisions in which a federal claim had been raised and rejected by the state court. ${ }^{128}$ In Judge Gibbons's view, the Supreme Court's jurisdiction was an important political reality, for it allowed the Federalists to reassure the British that even after the adoption of the Eleventh Amendment the treaty was enforceable in federal court, at least ultimately, on appeal. ${ }^{129}$ Second, there was the possibility that Congress would pass an original federal question jurisdictional statute.

I am not comfortable going as far as Judge Gibbons, who argues that the adopters of the Eleventh Amendment specifically intended to allow enforcement under federal question jurisdiction. I think it is possible that they had this intent, and Judge Gibbons

Gallatin was "not particularly welcome to that Federalist stronghold." Id at 1932.

${ }^{126}$ Unreported, discussed in Jacobs, Eleventh Amendment at 60-62 (cited in note 13).

See discussion at text and note 66 .

127 Gibbons, 83 Colum L Rev at 1936 (cited in note 8).

${ }^{128}$ Judiciary Act of 1789 , ch $20, \S 25,1$ Stat $73,85-87$.

${ }^{129}$ Gibbons, 83 Colum L Rev at 1935-37 (cited in note 8). I am not as confident as Judge Gibbons that the state courts were then thought to be under the obligation, or to have the power, to entertain unconsented private suits against the states, even when brought under federal law. There was no federal statute requiring the state courts to take federal questions suits that would abrogate the states' sovereign immunity. (Section 25 of the Judiciary Act of 1789 spoke directly to the appellate jurisdiction of the Supreme Court, not to the original jurisdiction of the state courts, and it said nothing about suits against a state.) Nor was there any provision of Article III explicitly requiring the state courts to take unconsented suits against the states. Perhaps under these circumstances, it was thought that the state courts had no obligation to entertain such suits, and, if they entertained them, no power to compel the states to appear. 
has carefully and skillfully marshalled considerable evidence in support of his view. But my reading of the evidence is more cautious. As I see it, the vulnerability of the states to unconsented suits by private citizens under federal law-in federal or state court-was an unresolved matter when the Eleventh Amendment was adopted. ${ }^{130}$

But Judge Gibbons's argument about Gallatin's proposal comports with my view just as well as with his own. Under either view, the rejection of Gallatin's language did not mean that the amendment was intended to prohibit suits brought by out-of-staters or foreigners. It only meant that the adopters did not want to preserve party-based jurisdiction for treaty cases. Indeed, if one views the amendment as a ringing victory for the anti-Federalists, as Professor Massey does, my view of the federal question issue makes the diversity explanation stronger than does Judge Gibbons's view. Under my view, there was some uncertainty about the power of Congress to abrogate state sovereign immunity in federal question cases, and I am less certain than Judge Gibbons that the state courts were required to be open to treaty claims. If this is so, the rejection of Gallatin's amendment left the enforceability of the treaty in greater doubt than under Judge Gibbons's explanation. In that event, of course, the anti-Federalists prevailed to a greater extent than under Judge Gibbons's view of the matter.

b. Protection against unconsented suits. Second, Professor Massey makes a related argument that Massachusetts, Virginia, and Georgia would have wanted more security against unconsented suits than a mere repeal of the state-citizen diversity jurisdiction would have provided. ${ }^{131}$ Professor Massey quite rightly points out that repeal of party-based jurisdiction might have been sufficient for the moment, but might not have been sufficient in the long run because Congress could pass a statute conferring original federal question jurisdiction on the federal courts, causing "all of these claims (or others very much like them) [to] emerge from their slumbers and reassert themselves in federal courts." ${ }^{\text {132 }}$ But if Professor Massey's reading of the amendment is correct, the adopters were unaccountably inept. The problem is by now familiar. Since only suits by out-of-staters and foreigners were prohibited, the possibility of suits by in-staters was left open, as was the possibility of assignment by out-of-staters and foreigners of their claims to

130 Fletcher, $35 \mathrm{Stan}$ L Rev at 1077-78 (cited in note 8).

131 Massey, 56 U Chi L Rev at 114-15 (cited in note 11).

132 Id at 115. 
in-staters. ${ }^{133}$

Massachusetts, Virginia, and Georgia may have wanted true security against such suits, but they did not get it. A day after the Court's decision in Chisholm, Representative Theodore Sedgwick of Massachusetts introduced the proposed amendment, described earlier, that would have fully protected the states. Sedgwick's version provided, in language quite different from that of the adopted version, that "no state shall be hable to be made a party defendant" in any federal court "at the suit of any person or persons whether a citizen or citizens, or a foreigner or foreigners, of any body politic or corporate, whether within or without the United States."134 But the next day a substitute was introduced that limited the amendment to out-of-staters and foreigners, and it is this language, witl the words "be construed" added later, that eventually became the Eleventh Amendment. ${ }^{135}$

c. Statutory versus constitutional amendment. Finally, Professor Massey argues that had the drafters only intended a repeal of the party-based jurisdiction that liad caused the trouble in Chisholm, a repeal of $\S 13$ of the Judiciary Act of 1789 would have accomplished that result. ${ }^{136}$ A constitutional amendment, according to Professor Massey, was not necessary. It is not clear how this argument refutes the diversity explanation. That the adopters chose a constitutional repeal rather than a statutory repeal of the state-citizen jurisdiction means only that they chose one manner of repeal over another.

Even thougl proponents of the diversity explanation need not explain why a constitutional rather than a statutory repeal was chosen, there is an obvious explanation. ${ }^{\mathbf{1 3 7}}$ At the time, considerable doubt existed about whether $\S 13$ was necessary for the Supreme Court to exercise state-citizen party-based jurisdiction. Jus-

193 See text at notes 102-09. Professor Massey does not discuss the assignment problem. He could defend his position, at least to some degree, by pointing out that he is not as sure as Professor Lawrence Marshall that suits by in-staters were intended to be preserved. If the vulnerability of the states to federal question suits by iu-staters was unclear, then the foolishness of speaking only to out-of-staters and foreigners is less obvious.

134 See text at notes $45-46$.

${ }^{135} 3$ Annals of Congress 651-52 (Feb 20,1793). Given the sparseness of the record, it is unclear whether Sedgwick regarded the rejection of his proposal as a serious defeat. We do know that Sedgwick voted to approve the amendment in its final form. 4 Annals of Congress 477 (March 4, 1794).

${ }^{138}$ Massey, 56 U Chi L Rev at 115-16 (cited in note 11).

${ }^{137}$ In addition to the argument advanced in the text, another possible explanation is that Congress wished to remove not only the jurisdiction under the existing statute, but also the possibility that such a statute could be passed later. However, I am not aware of any evidence that specifically speaks to this suggestion. 
tice Iredell, dissenting in Chisholm, had argued that statutory implementation of the constitutional grant was necessary, and he based his dissent on the failure of $\S 13$ (as he read it) to confer that jurisdiction. ${ }^{138}$ Iredell objected to Attorney General Randolph's argument before the Court in Chisholm that the Supreme Court's original jurisdiction was self-executing-in Randolph's words, that the Supreme Court "is to exercise all the judicial power vested in it by the constitution, by its own authority, whether the legislature has prescribed methods of doing so, or not." ${ }^{139}$ The four justices who voted in favor of the jurisdiction in Chisholm discussed neither $\S 13$ nor the disagreement between Iredell and Randolph. Thus, the Attorney General of the United States appears to have thought the jurisdiction self-executing, and four of the five justices of the Supreme Court may have agreed with him. ${ }^{140}$ Under the circumstances, one could readily understand why members of Congress wishing to repeal the state-citizen party-based jurisdiction would have done so by constitutional amendment. ${ }^{141}$ Merely repealing $\S 13$ would have invited a reaffirmance of Chisholm.

\section{B. Response to Professor William Marshall}

Professor William Marshall contends that the "core concern that the eleventh amendment was intended to reflect" was the protection of "state treasuries against any federal court intrusion."142 In his view, the "diversity theorists" have not met the burden of proving that "a proper historical understanding [of the amend-

138 See text at notes $39-44$.

1392 US (2 Dall) at *432. Randolph argued, "1st. That the constitution vests a jurisdiction in the supreme court over a state, as a defendant, at the suit of a private citizen of another state. $2 \mathrm{~d}$. That the judicial act recognises [sic] that jurisdiction." Id at *420 (emphasis added). See also id at ${ }^{*} 426$ ("The judicial act recoguises [sic] the jurisdiction over states.").

1s0 Professor Clinton's careful analysis of Chisholm accords with my reading of the opinions. Professor Clinton would go farther, contending that at least Justice Wilson affirmatively agreed with Randolph's argument. Robert N. Clinton, A Mandatory View of Federal Court Jurisdiction: Early Implementation of and Departures from the Constitutional Plan, 86 Colum L Rev 1515, 1563-68 (1986).

141 Professor Jackson has advanced the same explanation for the overruling of Chisholm by constitutional amendment. Jackson, 98 Yale L J at 45 and $n 184$ (cited in note 8) (noting that counsel in Rhode Island $v$ Massachusetts, 37 US (12 Pet) 657, 699 (1838), relied on this explanation), and $49 \mathrm{n} 195$. I do not regard it as established that, in fact, the Supreme Court's original jurisdiction was intended by the framers to be self-executing. I do regard it as relatively clear, however, that four of the five justices in Chisholm might reasonably have been thought by the adopters of the Eleventh Amendment to have held that opinion.

142 W. Marshall, 102 Harv L Rev at 1396 (cited in note 10) (emphasis added). 
ment] establishes that states should not be immune from federal question suits for monetary relief in federal court.".143 My response may seem somewhat odd, given that I am one of the "diversity theorists," but I agree with most of Professor William Marshall's arguments. I respond in this way for two reasons. First, the diversity explanation, as he describes it, goes beyond what I believe can be conclusively demonstrated to have been intended by the adopt$\hat{e r s}$ of the amendment. Hence, I agree that the adopters cannot be shown to have had a fully formed intent to preserve federal question suits. Second, some of Professor William Marshall's arguments seek to establish propositions that I see as both true and entirely consistent with the diversity explanation.

\section{Poor drafting.}

Professor William Marshall begins by stating that the amendment is badly drafted. He thinks it quite unlikely that the adopters of the amendment intended to prohibit suits by out-of-staters and foreigners, while at the same time leaving suits by in-staters unaffected. ${ }^{144} \mathrm{He}$ does not quite endorse the Court's decision in Hans $v$ Louisiana, ${ }^{\mathbf{1 4 5}}$ which held that the Eleventh Amendment bars unconsented suits brought by in-state citizens, but he thinks that the adopters of the amendment failed to say what they meant: "Unfortunately, the wording of the amendment reflects the haste with which it was proposed."146

Professor William Marshall's assumption that the text of the amendment is the result of ill-considered drafting is probably wrong. If he is arguing that the drafters were too hurried to consider their words carefully, the timetable in the record contradicts him. ${ }^{147}$ The first proposed amendment to overturn Chisholm was introduced in the House by Representative Sedgwick on February 19,1793 , the day after Chisholm was announced. A second version was introduced the next day. Congress adjourned on March 4 without taking further action. Congress reconvened on December 2, 1793. On January 2, 1794, a third version of the amendment was proposed in the Senate. On January 14, Senator Gallatin's

143 Id at 1375.

14 Id at 1378.

145134 US 1 (1890). "Hans divorced the text of the eleventh amendment from its interpretation. Yet, even if the eleventh amendment's text can be overlooked, a glaring lack of any other textual support for the position that states are immune from federal court suits based on federal law remains." W. Marshall, 102 Harv L Rev at 1380 (cited in note 10).

${ }_{146}$ W. Marshall, 102 Harv L Rev at 1378 (cited in note 10).

${ }^{117}$ See text at notes $44-53$. 
proposal to add the language discussed above ${ }^{148}$ was defeated. An unknown senator immediately thereafter proposed the addition of other language, which was also defeated. ${ }^{149}$ The final version of the amendment was approved by the Senate on the same day. One attempt was made to add language in the House on March 4, 1794, but that was also defeated. ${ }^{150}$ The amendment then passed the House on the same day. In sum, just over a year elapsed between the introduction of the first proposal and the approval of the final version. During that time, a total of six different versions were considered. Although the initial reaction to Chisholm-Representative Sedgwick's proposed amendment-was "immediate and hostile,"161 the drafting process as a whole was relatively deliberate.

Professor William Marshall's bad drafting argument may also rest on the assumption that it is implausible that the adopters wished to prohibit suits by out-of-staters and foreigners, and at the same time to leave in-staters unaffected. I agree that this is implausible, but one would conclude that the drafting was careless only if one reads the amendment as prohibiting jurisdiction. As we have seen, other amendments proposed in the early 1800 s provide fairly strong evidence that the adopters understood the language to repeal rather than prohibit party-based jurisdiction. ${ }^{\mathbf{1 5 2}}$ If we understand the language of the amendment as only a repeal, then out-of-staters, foreigners, and in-staters are treated identically: there is no party-based jurisdiction for any of them. One can thus conclude both that the words of the amendment were chosen with care, and that the adopters did not intend to distinguish among the various kinds of possible plaintiffs.

\section{The possibility of federal question based suits.}

Professor William Marshall then attacks three arguments in support of the diversity explanation. First, he attacks the argument that the adopters of the amendment focused only on the state-citizen diversity clause, and were not greatly concerned by the possibility of suits brought against the states under federal law. ${ }^{153}$ I made this argument in its most emphatic form in $1983 .{ }^{154}$

148 See text at notes 121-31.

149 Gibbons, 83 Colum $\mathrm{L} \mathrm{Rev}$ at 1933 (cited in note 8).

${ }^{130}$ Fletcher, 35 Stan L Rev at 1059 (cited in note 8).

${ }^{151}$ Id at 1058. See also W. Marshall, 102 Harv L Rev at 1377 (cited in note 10) ("As commentators are fond of saying, the reaction to Chisholm v. Georgia was 'swift and hostile.'").

${ }^{152}$ See discussion, text at notes $82-90$.

1ss W. Marshall, 102 Harv L Rev at $1381-83$ (cited in note 10). 
Since writing that article, however, I have been convinced ${ }^{155}$ that the adopters were conscious of the possibility of suits brought against the states under federal law, primarily claims under the 1783 peace treaty with the British. ${ }^{156}$

Judge Gibbons has concluded that the adopters were not only conscious of these suits, but affirmatively intended to preserve federal court jurisdiction, particularly the existing Supreme Court appellate jurisdiction over state court decisions in federal question suits under $\S 25$ of the Judiciary Act. As I indicated earlier, I am not yet convinced that the adopters were affirmatively addressing that question. ${ }^{157}$ It seems to me at least as likely that they were simply postponing it. As things turned out, the treaty-based claims were soon shunted off to an international commission, so the Supreme Court was never asked under its $\S 25$ jurisdiction whether the states were required to entertain in their own courts unconsented treaty-based suits. ${ }^{158}$ Further, although the issue of the relationship between the Eleventh Amendment and federal question jurisdiction was raised in several cases before the Civil War, the Supreme Court never resolved it. ${ }^{159}$

It now appears to me that Professor William Marshall is right that the adopters of the amendment were conscious of the federal question suits that would certainly be brought if Chisholm were left standing, and that might well be brought if federal question suits were not forbidden. But this does not mean that they intended the amendment to prohibit such suits. Recall that the adopters rejected Representative Sedgwick's original version of the amendment, which would have protected the states from all suits. The states were concerned about the protection of their treasuries, as Professor William Marshall says, but the diversity explanation of the amendment is consistent with that concern. After the repeal of the party-based jurisdiction, the treasuries were in fact protected, since there was, at least for the time being, no statutory

${ }^{154}$ Fletcher, 35 Stan L Rev at 1077-78 (cited in note 8).

${ }^{155}$ See Gibbons, 83 Colum L Rev at 1926-41 (cited in note 8).

${ }^{158}$ In my earlier article, I foolishly suggested that foreigners were included in the amendment in part because of the rumor (false, as it turned out) that the plaintiff in Chisholm had been British. Fletcher, 35 Stan L Rev at $1045 \mathrm{n} 52$ (cited in note 8). It is now clear to me, thanks to Judge Gibbons, that the claims of British subjects under the peace treaty were the concern.

157 See text at note 130 .

158 Gibbons, 83 Colum L Rev. at 1940 (cited in note 8). I think it possible the Supreme Court would have held that the states were not required to do so. See note 129 .

158 Fletcher, 35 Stan L Rev at 1083-87 (cited in note 8); Gibbons, 83 Colum L Rev at 1941-68 (cited in note 8); and Jackson, 98 Yale L $\mathrm{J}$ at 15-25 (cited in note 8). 
grant of original federal question jurisdiction to the lower federal courts. There was the long and uncertain route through the state courts and up to the Supreme Court under $\S 25$, but it had not been tested in a suit for money brought under federal law. ${ }^{160}$

\section{The "Plan of the Convention."}

Professor William Marshall also attacks the argument that the "plan of the convention" required the preservation of unconsented suits against the states to enforce federal law. ${ }^{161} \mathrm{He}$ first makes the attack in general terms, ${ }^{162}$ but then narrows it to an attack on the argument that the adopters intended to preserve the ability to sue the states for damages under federal law. ${ }^{163}$ Professor Marshall has put his finger on a sensitive point. He is clearly correct that the framers of the Constitution and the adopters of the Eleventh Amendment were very concerned about unconsented suits against the states for damages. For example, Hamilton had argued in Federalist $81^{164}$ that the state-citizen diversity clause did not mean that state indebtedness to individuals would be subject to compulsory suit in federal court. A damage suit had been at issue in Chisholm, and of course the amendment was intended specifically to change the outcome in that case. Moreover, Justice Iredell had specifically said that he thought every part of the Constitution could be given full effect without authorizing suits "for the recov-

${ }^{160}$ The Court did subsequently hear Cohens $v$ Virginia, 19 US (6 Wheat) 264 (1821), which is commonly cited today for the proposition that the Supreme Court is not limited by the Eleventh Amendment in cases coming up from the state courts. As Professor Jackson is careful to point out, this is an extreme overreading of Cohens. Jackson, 98 Yale $\mathrm{L} J$ at 15 (cited in note 8). The Court in Cohens held only that it could hear a writ of error in a criminal case, where defendants claimed a violation of a federal right.

161 W. Marshall, 102 Harv L Rev at 1383-89 (cited in note 10). Professor Marshall notes that Justice Brennan referred to the "plan of the convention" in Atascadero State Hospital $v$ Scanlon, 473 US 234, 280 (1985) (Brennan dissenting). Professor Marshall characterizes the "plan of the convention" argument as positing "that the participation of the stato in the constitutional compact inherently required the states to submit to the constitutional limits imposed by that compact, including the limits imposed by the federal government pursuant to its delegated powers."

162 W. Marshall, 102 Harv L Rev at 1384-85 (cited in note 10).

16s Id at 1384, 1385 ('[T] position ... was not consistent with the framers' views of state susceptibihity to suits for monetary relief. ... Most critically, however, the 'plan of the convention' theory ignores that the central objection to Chisholm, as well as the general objection to federal jurisdiction raised in the constitutional debates, was the fear of federal judicial invasion of state treasuries.").

${ }^{164}$ Federalist 81 (Hamilton) in Clinton Rossiter, ed, The Federalist Papers 481, 487-88 (New Am Lib, 1961). See also Fletcher, $35 \mathrm{Stan} L$ Rev at 1047-48 n 63-64 (cited in note 8); Gibhons, 83 Colum L Rev at 1910-11 (cited in note 8). 
ery of money." "165

I take Professor William Marshall's position to be that if the issue had been squarely presented in the 1790 s or early 1800 s, the Supreme Court may well have allowed federal question suits for prospective relief, but not for the recovery of money. Judge Gibbons argues that the adopters specifically intended to allow suits for the recovery of money under the peace treaty. ${ }^{166}$ Professor Amar argues that if a damage remedy was necessary for the implementation of a constitutional right, the amendment should not be understood as eliminating that remedy. ${ }^{167}$ And I have argued that if it were within the federal legislative power to provide for a damage remedy against the states, the federal judicial power would have extended as far as the legislative power. ${ }^{168}$ But Professor William Marshall may be right. We simply cannot know, for the question was never squarely presented. ${ }^{169}$ In the end, however, I understand William Marshall to accept the proposition that the amendment did not affect federal question jurisdiction. The critical issue for him is what remedies were to be permitted under the federal question jurisdiction, which is quite a different matter from arguing that federal question jurisdiction was foreclosed altogether by the amendment.

I am not sure whether the adopters of the amendment specifically intended to allow suits for damages under federal law. There is evidence on both sides. The adopters clearly knew that there were suits for the recovery of money waiting to be brought, and that Vassall $v$ Massachusetts ${ }^{170}$ was already filed. But just as clearly, the amendment itself did not forbid the bringing of suits based on federal law. It certainly did not do so for in-state citizens; and as I understand the amendment, it did not do so for out-ofstaters and foreigners. The questions left unanswered were whether federal question jurisdiction, acting without the assistance of the state-citizen diversity clause, could subject the states to unconsented suits under federal law; and if federal question suits

${ }^{185} 2$ US (2 Dall) at *449 (Iredell dissenting).

${ }^{168}$ Gibbons, 83 Colum L Rev at 1934-36 (cited in note 8).

${ }_{167}$ Amar, 96 Yale L J at 1484-92 (cited in note 8).

${ }_{168}$ Fletcher, 35 Stan L Rev at 1074 (cited in note 8).

${ }^{169}$ Moreover, even if the question had been addressed, we would have trouble fitting an answer from the 1790 s or 1800 s into our modern system, given that damage judgments were then much more freely available against state officers than they are today. David E. Engdahl, Immunity and Accountability for Positive Governmental Wrongs, 44 U Colo L Rev 1, 41 (1972).

${ }^{170}$ Unreported, discussed in Jacobs, Eleventh Amendment at 60-62 (cited in note 13). 
could be brought, under what provisions of federal law and for what remedies? As we know from modern law, these are exceedingly complicated and multifarious questions. ${ }^{171}$ And, as I read the rather sparse historical evidence, these questions were not intended to be answered by the Eleventh Amendment.

\section{The Eleventh Amendment and the source of law.}

Finally, Professor William Marshall attacks an argument advanced by Professor Amar in support of the diversity explanation. ${ }^{172}$ Professor Amar has argued that in Chisholm the Supreme Court held that Georgia could not claim sovereign immunity in a suit based on its own law. In so doing, he argued, it either misapplied state law, or improperly usurped state law by applying the court federal common law. ${ }^{173}$ In either event, the Court violated $\S$ 34 of the Judiciary Act ${ }^{174}$ and the principle that led to Erie Railroad $v$ Tompkins. ${ }^{175}$ The Eleventh Amendment was passed, Professor Amar concluded, to correct this mistake. Professor William Marshall contends that this argument is an anachronistic anticipation of Erie. I agree.

Professor William Marshall is obviously correct that we must deal with jurisprudential categories as they were used in the 1790s rather than as they are used in the twentieth century. At the time of Chisholm, the federal courts understood $\S 34$ of the Judiciary Act merely to declare what the practice would have been in the absence of the section-that the federal courts would apply whatever law was appropriate to the case at hand. In the majority of cases, the appropriate law was the "common law" (what we would today more readily call the "general common law"). ${ }^{176}$ At the time, the common law was not "state law," which was understood to be local law that covered matters either not comprised within the common law or that deviated from the common law.

${ }^{171}$ See, for example, discussion in Field II, $126 \mathrm{U} \mathrm{Pa} \mathrm{L} \mathrm{Rev} \mathrm{at} \mathrm{1209-1277} \mathrm{(cited} \mathrm{in} \mathrm{note}$ 7); Fletcher, 35 Stan L Rev at 1087-1130 (cited in note 8); and Jackson, 98 Yale L J at 72126 (cited in note 8).

${ }^{172}$ W. Marshall, 102 Harv L Rev at 1390-95 (cited in note 10). Professor Amar's argument is in 96 Yale $\mathrm{L} J$ at $1470-75$ and $n 202$ (cited in note 8).

173 Amar, 96 Yale $L J$ at 1474 (cited in note 8).

174 Judiciary Act of 1789 , ch $20, \S 34,1$ Stat 73,92 , which provides: "That the laws of the several states, except where the constitution, treaties or statutes of the United States shall otherwise require or provide, shall be regarded as the rules of decision in trials at common law in the courts of the United States in cases where tbey apply."

178304 US 64 (1938).

176 Fletcher, 97 Harv L Rev at 1515 n 9 (cited in note 68). 
Nor was the common law federal law that could supplant (or, in modern terminology, preempt) state law. Common law was rather a general law shared by the American states and followed voluntarily by them. The underlying contract dispute in Chisholm was treated by the Court as a question of common law rather than as a question of local (or state) law, or as a question of federal law. ${ }^{177}$ All this is consistent with the diversity explanation of the Eleventh Amendment.

The Court in Chisholm held that Georgia could be compelled to appear to defend the common law contract suit brought by an out-of-state citizen. Whether Georgia was actually liable on this contract under the common law was not decided by the Court, but I think it a fair reading of Chisholm (and of the reaction of those who adopted the Eleventh Amendment) that the Court's holding meant that Georgia would have no defense to the contract based on the fact of its sovereignty. That is, after Chisholm Georgia's sovereign immunity defense was unavailable and it would have to defend the suit in much the same fashion as a private defendant. The source for the Court's holding that Georgia's sovereign immunity was abrogated was not the common law, but rather the only federal law with bearing on the case-the state-citizen diversity clause. That clause abrogated the sovereign immunity of a state whenever a suit was brought under the party-based jurisdiction specified in the clause. The adopters of the Eleventh Amendment reacted in a perfectly rational way to Chisholm, by repealing the federal question jurisdictional provision that was the source of the abrogation.

In order to understand the significance of the repeal of the state-citizen diversity clause, we need to divide sovereign immunity into several components. In my earlier article, I set out a lengthy analysis of how these components should bear on our understanding of the Eleventh Amendment. ${ }^{178}$ I will give only a summary here, but it should be enough to explain how it can simultaneously be true that Professor Marshall is right that we must understand the amendment by reference to the categories of law used in the 1790 s, and that the adopters intended only to repeal the jurisdictional grant in the state-citizen diversity clause.

In general, sovereign immunity is the ability of a sovereign legitimately to refuse to submit to judicial process in a suit brought

${ }^{177}$ See, for example, 2 US ( 2 Dall) at $* 453, * 458, * 465$, and ${ }^{*} 466$ (1793) (Wilson). See also W. Marshall, 102 Harv L Rev at $1391 \mathrm{n} 107$ (cited in note 10).

${ }^{178}$ Fletcher, 35 Stan L Rev at 1063-78 (cited in note 8). 
against it. One of the components of that sovereign immunity is the ability to object to suit by any private person. In the United States after the adoption of the Constitution, this component could be further broken down into subcomponents depending on the source of the cause of action and on the court in which the suit is filed. We are here concerned with suits in federal court that could be brought under either common law or state law (i.e., nonfederal law), or under federal law. ${ }^{179}$ Chisholm was a suit of the first type, brought under the common law. The Eleventh Amendment, in overruling Chisholm, repealed the grant of jurisdiction that had required the state to submit to suit under the common law, and thus prevented the federal government from finding that a state had given up its sovereign immunity in suits brought under non-federal law.

Suits brought under federal law were something else again. In these suits, the issue was not whether a state should be bound by non-federal law (including both local state law and common law, which it could change or depart from whenever it chose). Rather, the issue was whether a state could be judicially compelled to obey the law of a superior sovereign. The federal law question, unlike the Chisholm question, was whether the states in subscribing to the Constitution gave up their sovereign immunity to suits brought under the new federal law that was created or authorized by the new Constitution. These questions are so different that it is implausible that the adopters of the Eleventh Amendment should have thought that the answer to the first question necessarily entailed the answer to the second.

\section{CONCLUSION}

Professor Lawrence Marshall writes that the diversity theorists appear to claim that they have "incontrovertible evidence" to support their explanation of the Eleventh Amendment. ${ }^{180}$ Evidence of that character would be surprising here, where the historical record is so sparse and the questions so complicated. Yet, despite the absence of such evidence, the diversity explanation seems to me demonstrably superior to any competing explanation: the

179 Id at 1070 . To some degree, the argument here depends on an understanding of the relationship among federal law, general common law, and local state law that I developed in an article that was in manuscript when my Eleventh Amendment article went to press. Fletcher, 97 Harv L Rev 1513 (cited in note 68). See W. Marshall, 102 Harv L Rev at 1393 n 118 (cited in note 10) (citing this article).

${ }^{180}$ L. Marshall, 102 Harv L Rev at 1350 (cited in note 11). 
amendment was intended to require a narrower construction of the grant of jurisdiction contained in the state-citizen diversity clause and the state-foreigner diversity clause. After the adoption of the amendment, the federal courts no longer had party-based jurisdiction when an out-of-state citizen, or a foreign citizen or subject, sued a state. The amendment was not intended to prohibit jurisdiction in such cases, however. Other heads of jurisdiction-federal question jurisdiction and admiralty jurisdiction, in particular-were not disturbed.

The question of greatest interest to many modern scholars is whether the states were intended to have sovereign immunity from suits brought by private individuals under federal law. The diversity explanation does not directly answer that question. Rather, it tells us that the answer cannot be found in the Eleventh Amendment at all. Whatever judicial power existed under the other heads of jurisdiction before the passage of the amendment continued to exist after its passage. Some scholars, most prominently Judge Gibbons and Professor Amar, believe that federal question jurisdiction clearly entailed, at the time of the adoption of the Eleventh Amendment, an abrogation of the sovereign immunity of the states in federal court. For my own part, I think that it was a difficult and unresolved question that was left by the framers, as well as by the adopters of the Eleventh Amendment, to be answered as the meaning of the Constitution unfolded.

I suggested in my earlier article what the consequences might be if the diversity explanation of the amendment is accepted as the best available historical account, and if that explanation is permitted to have a significant role in shaping modern doctrine. ${ }^{181} \mathrm{I}$ will focus here only on the ability to sue a state in federal court under the federal question jurisdiction. ${ }^{182}$ Some "diversity theorists" believe that the framers of the Constitution and the adopters of the amendment specifically intended for there to be an abrogation of the states' sovereign immunity under the federal question jurisdic-

182 Fletcher, 35 Stan L Rev at 1091-1130 (cited in note 8). The three consequences I do not discuss here are: (1) that state sovereign immunity would not be analogized to ordinary federal court subject matter jurisdiction under Mansfield, Coldwater \& Lake Michigan Ry. $v$ Swan, 111 US 379 (1884); Fletcher, 35 Stan L Rev at 1091-93 (cited in note 8); (2) that it would be unnecessary to decide whether the states can be compelled to hear private suits against themselves in their own courts under Testa v Katt, 330 US 386 (1947); Fletcher, 35 Stan L Rev at 1093-99 (cited in note 8); and (3) tbat the present distinction between a state, which is protected by the amendment, and its subdivisions, which are not, would become much less important, 35 Stan L Rev at 1099-1107 (cited in note 8).

182 Fletcher, 35 Stan L Rev at 1108-1130 (cited in note 8). 
tion. ${ }^{183}$ Other "diversity theorists," including me, believe that the question of the states' sovereign immunity under the federal question jurisdiction was left open by the framers and the adopters. ${ }^{184}$ Finally, "Congressional abrogation theorists" believe that the amendment (and the idea for which it stands) was intended to prohibit suits by private individuals, but to permit Congress to abrogate that immunity by legislation. ${ }^{185}$ The majority of the Supreme Court apparently still believes that the amendment forbids jurisdiction for out-of-staters and foreigners, and that Hans $v$ Louisi$a n a^{186}$ filled in a missing term when it extended the prohibition to in-staters. ${ }^{187}$

Oddly enough, all ways of thinking about the amendment have led more or less to the same place. The "diversity theorists" get there fairly directly, the "Congressional abrogation theorists" a little less so, and the Supreme Court less directly still. But they all conclude that there is nothing in the history of the Eleventh Amendment to prevent the federal government from providing for unconsented suits against the states under federal law, even when the remedy includes an order for the recovery of money directly from the state treasury. There are differences among these theories and their implications, but it is striking that the theories, and the results reached by the Supreme Court, all confirm the fundamental insight of the diversity explanation: private suits against a state under its own law should be the affair of the state and its own courts, but suits under federal law are quite another matter. Today we have come to believe that inherent in the Constitution is the congressional power to authorize federal courts to enforce federal law against the states at the instance of private individuals who are supposed to be protected by those laws. There is disagreement over what federal laws should control the states, what constitutional provisions they should be based upon, and what remedies should be available. But that there should be such suits, and that the remedies made available should be meaningful implementations of the federal rights at issue, are beyond substantial debate.

${ }^{183}$ Amar, 96 Yale L J at 1466-75 (cited in note 8); Gibbons, 83 Colum L Rev at 1899 (cited in note 8).

184 Field I, 126 U Pa L Rev at 534-36, 543-45 (cited in note 7); Fletcher, 35 Stan L Rev at 1068-69, 1077-78 (cited in note 8); and possibly Jackson, 98 Yale L J at 1 (cited in note 8).

18s Nowak, 75 Colum L Rev at 1422 (cited in note 8); Tribe, 89 Harv L Rev at 693 (cited in note 8).

188 134 US 1 (1890).

${ }^{187}$ Pennsyluania v Union Gas, 109 S Ct 2273, 2277 (1989). 
HeinOnline -- 56 U. Chi. L. Rev. 13001989 